\title{
The muscles, body wall and valve-opening mechanism of extant craniid (inarticulated) brachiopods
}

\author{
Jeffrey Robinson* \\ Department of Geology, University of Otago, Dunedin, New Zealand
}

(Received 17 May 2013; accepted 1 September 2013; first published online 18 February 2014)

\begin{abstract}
Specimens of six species of craniid brachiopod were dissected and the musculature, body wall and mantle were examined. New names are proposed for the "brachial protractor" and "brachial retractor" muscles. The "brachial elevator" muscles are part of the anterior adductor muscles, a small bundle of translucent quick-muscle partially enclosed by a larger, curving bundle of the dark-coloured slow-muscle. A new ring muscle is described. The lophophore arms are extended and retracted by the hydrostatic skeleton and brachial muscles respectively. The valves of Novocrania are probably opened by the creation of hydrostatic pressure, within a newly described coelomic chamber, by contraction of the oblique lateral muscles. Neoancistrocrania has an extra pair of dorsal mantle canals arising at the posterior and a dorsally directed pouch in the body wall.
\end{abstract}

Keywords: hydrostatic; lophophore; mantle canals; muscles; Neoancistrocrania; Novocrania

\section{Introduction}

Craniid brachiopods have a very long fossil history and are largely unchanged since they first appeared in the Lower Ordovician (450 million years ago) (Bassett 2000). There are three genera still living in the modern oceans and the anatomy of living genera provides a great deal of valuable information to allow interpretation of fossil genera. However, the anatomy of the muscles of craniids has not been studied in detail since Blochmann (1892), and his work was carried out on a single species, Novocrania anomala (Müller, 1776). This is the first study for 140 years to look at certain aspects of craniid anatomy, uses modern microscopes and scanning electron microscopy, and examines the anatomy of two genera (six species) of craniid. The anatomy of $N$. anomala was first described by Joubin (1886) and a number of misconceptions in the literature about the anatomy of Novocrania, and other genera and species of craniid, date from this and later publications. These include the functions of various muscles, how, and how far, craniids extend and retract their lophophore arms and how craniids open their valves. Various authors have published text and diagrams that are inconsistent or that suggest an incorrect form or function of certain muscles. This study attempts to clear up these misconceptions and to introduce new information and terminology. Two muscles are renamed, and a new muscle and a new coelomic chamber are described. This study also figures variations in the dorsal mantle canals and body wall of Novocrania and

*Email: jeffreyhrobinson@yahoo.co.nz 
Neoancistrocrania, and discusses how craniids may extend and retract their lophophore and open their dorsal valves.

\section{Material and methods}

This study is based on dissections of specimens of six species of craniid from geographically widely separated sites, preserved in 70\% ethanol; Novocrania anomala, Novocrania japonica (Adams, 1863), Novocrania lecointei (Joubin, 1901), Novocrania huttoni (Thomson, 1916), Novocrania californica (Berry, 1921) and Neoancistrocrania norfolki Laurin 1992. Dry specimens of these six species and Novocrania turbinata (Poli, 1795) were also examined, some with and some without dried tissue (Table 1). The ethanol-preserved specimens were soaked in a solution of $50 \%$ detergent and $50 \%$ tap water for 24-48 hours to rehydrate the tissues. Digital photographs were taken with a Nikon Coolpix 995 camera attached to a Leica WILD MZ8 microscope. Scanning electron microscopy photographs were taken on a JEOL Cambridge electron microscope.

\section{Craniid musculature and function}

The muscle system of living Novocrania has been described and illustrated by a number of authors including Joubin (1886); Davidson (1886-1888); Oehlert (1887); Blochmann (1892); Shipley (1895); Delage and Hérouard (1897); Thomson (1927); Bulman (1939); Helmcke (1939); Rowell (1965) (as Crania), James (1997) and Williams et al. (1997) (as Neocrania). The names and suggested functions of the muscles of Recent Novocrania have varied considerably between different nineteenth and early twentieth century authors. The English version of the muscle names became standardized with Bulman (1939); Blochmann's (1892) anatomical study of inarticulated brachiopods is still the authoritative text for craniid anatomy today and most of the later texts are largely based on Blochmann's description of $N$. anomala.

Williams et al. (1997), the most comprehensive recently published account, described eight pairs of muscles and one unpaired muscle in Novocrania (Figure 1A, adapted from Blochmann 1892); two pairs of adductor muscles, posterior and anterior, that close the valves; one pair each of oblique internal and oblique lateral muscles that control the rotation and sliding movements of the valves; three pairs of muscles that control the position of the lophophore, the "brachial elevator", "brachial protractor" and "brachial retractor" muscles; a pair of brachial muscles, one in each arm of the lophophore; and the unpaired median muscle that attaches to the last stage of the alimentary tract.

Other movements of the dorsal valve carried out by various muscles have been described. Atkins and Rudwick (1962) stated that when the valves of N. anomala were closed slowly the dorsal valve swivelled from side to side as it approached the ventral valve "as though adjusting its position to ensure a tight fit" (by the oblique muscles). Rudwick (1970) noted that in Novocrania the valves are often snapped shut (by the adductor muscles) to eject faecal pellets and pseudofaeces (mucus-bound non-food particles) and that in some specimens the upper valve would slide forward (by the oblique muscles) before the valves opened. 


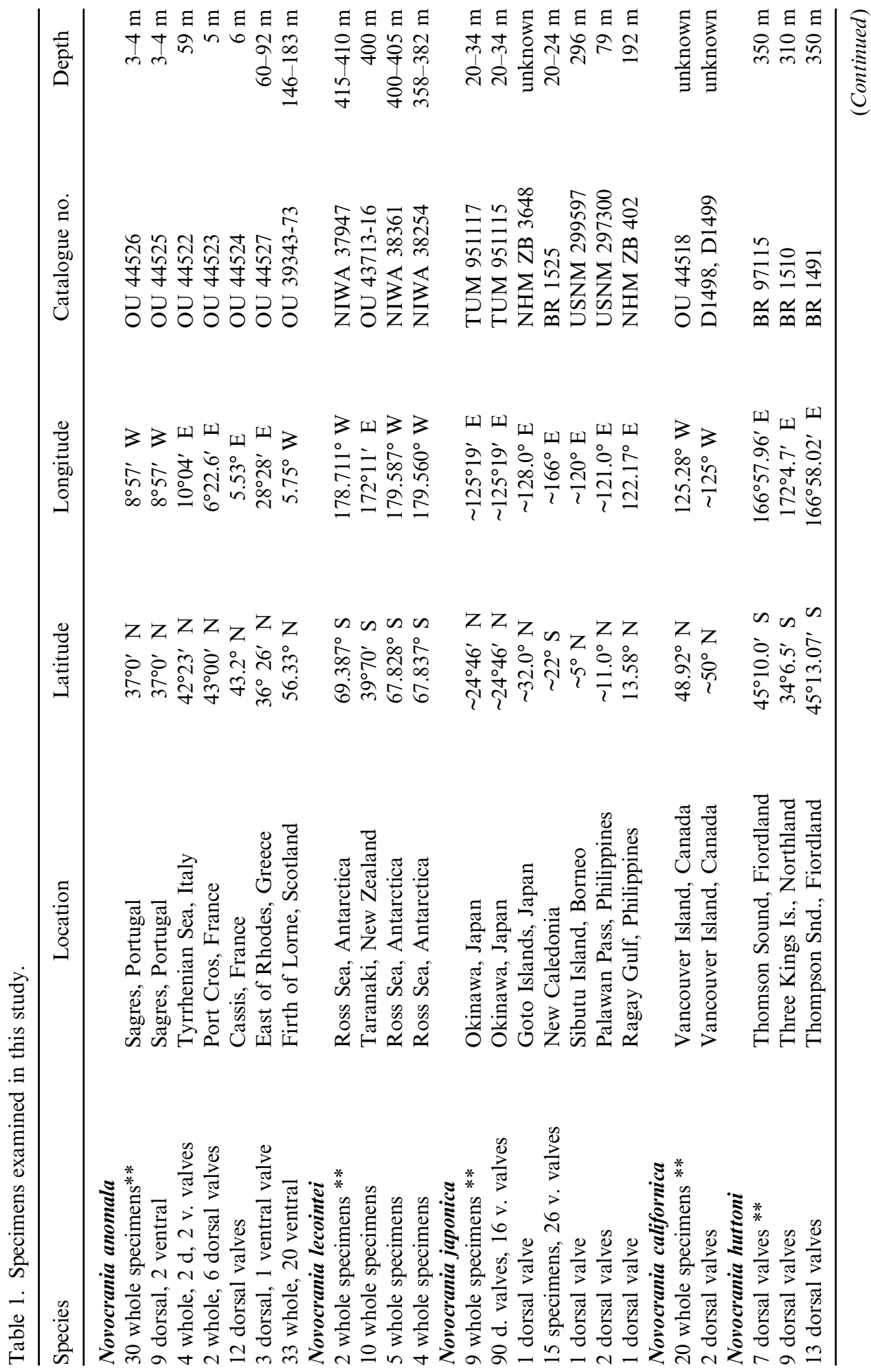




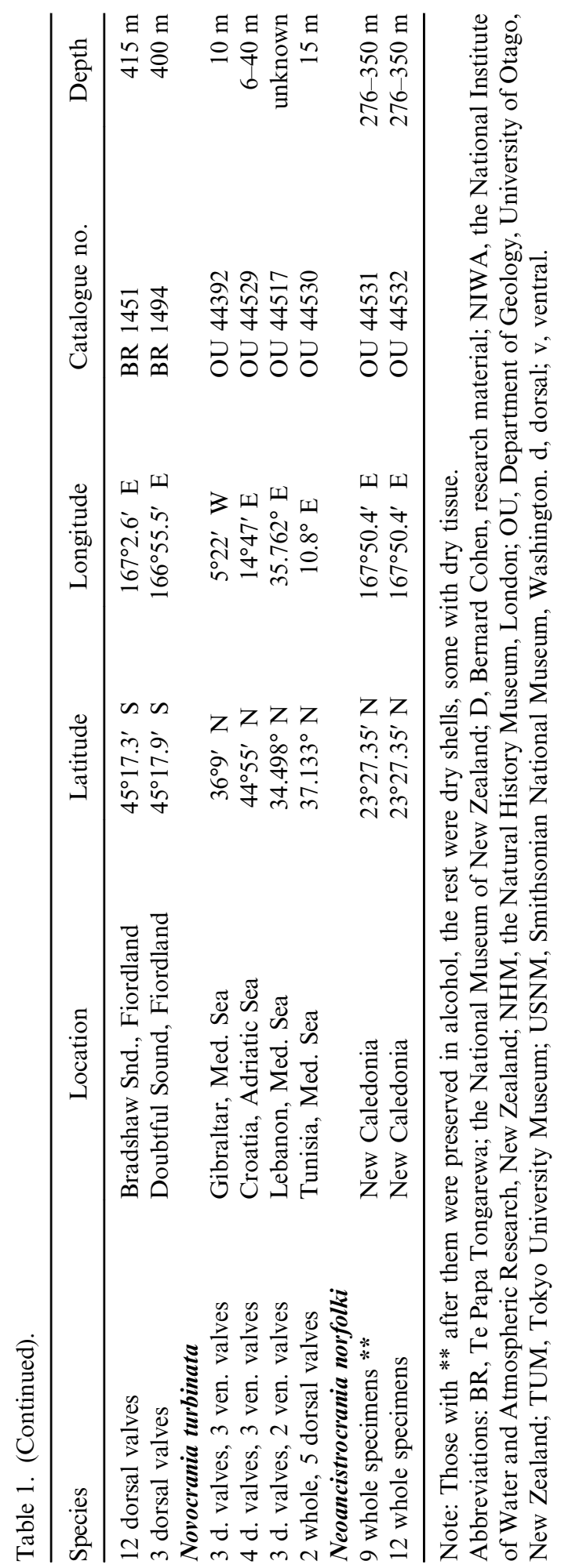




\section{Description of craniid muscles}

The muscles of craniids (Figure 1B-I) are composed of long, thin, flat, closely packed fibres that extend the entire length of each muscle (Figure 2A, B), there are no tendons as occur in articulated brachiopods. Each muscle is encased in a very thin transparent-whitish membrane. The names of the craniid muscles as presented in Blochmann (1892) and in this study, where some are renamed, are listed in Table 2.

\section{(1) The brachial muscles}

The brachial muscles run along the inner edge of each arm of the lophophore (Figures $1 \mathrm{E}-\mathrm{G}$ and 2C; Blochmann 1892, fig. 7) and attach to the anterior side of the muscular belt of the (newly proposed) ring muscle (Figure 1E).

\section{(2) The "brachial elevator" muscles}

Blochmann (1892) first used the term levatores brachorum. Blochmann figured the "brachial elevator" muscles as lying within the curve of, and considerably shorter than, the anterior adductor muscles, attached to the dorsal valve at one end and to connective tissue at the base of the brachial muscle at the other (Figure 1A; Blochmann 1892, fig. 58; Williams et al. 1997, fig. 105). Blochmann showed the "brachial elevator" and brachial muscles as separate structures. Shipley (1895, fig. 316), Thomson (1927, fig. 11) and Bulman (1939, fig. 4) figured the "brachial elevator" muscles as curving and Bulman (1939) stated that they "bend sharply forward to be inserted into the arms", suggesting that the "brachial elevator" muscle and the brachial muscle are continuous. This is almost certainly a misunderstanding of one of Blochmann's figures (1892, fig. 7) where the illustration makes the "brachial elevator" muscle appear to be continuous with the brachial muscle. Williams et al. (1997, fig. 84) used the figure by Bulman (1939) with curving "brachial elevator" muscles but stated "the brachial elevator muscles are found only in craniids and attach to the connective tissue at the base of the brachial muscle" (and so are not continuous with the brachial muscle).

In all species of craniid dissected in this study the "brachial elevator" muscles attach to both the dorsal and ventral valves and are sub-circular to hemispherical to sub-triangular in cross-section (Figures 1C and 2D). The muscle scars where the "brachial elevator" muscles attach to the dorsal and ventral valves are usually dimples within the curve of the anterior adductor muscle scars. In some species/ specimens the ventral dimples in particular are deep (Figure 1B), so the "brachial elevator" muscles are slightly to significantly longer than the anterior adductor muscles, not considerably shorter as illustrated by Blochmann (1892, fig. 9; Figure 1A). In all species dissected no connective tissue was found on the inner side of the body wall where the "brachial elevator" muscle would connect to the base of the brachial muscle of the lophophore.

This study suggests that craniids do not need to elevate the lophophore and that this interpretation by Blochmann (1892) was an error. No species dissected had a muscle that conformed to Blochmann's description of a "brachial elevator" muscle. This study suggests that the "brachial elevator" muscle is part of the anterior adductor muscle.

\section{(3) The anterior adductor muscles}

Previous authors (Blochmann 1892, fig. 9; Thomson 1927, fig. 11; Bulman 1939, fig. 4; Williams et al. 1997, fig. 84) have figured the anterior adductor muscles in 

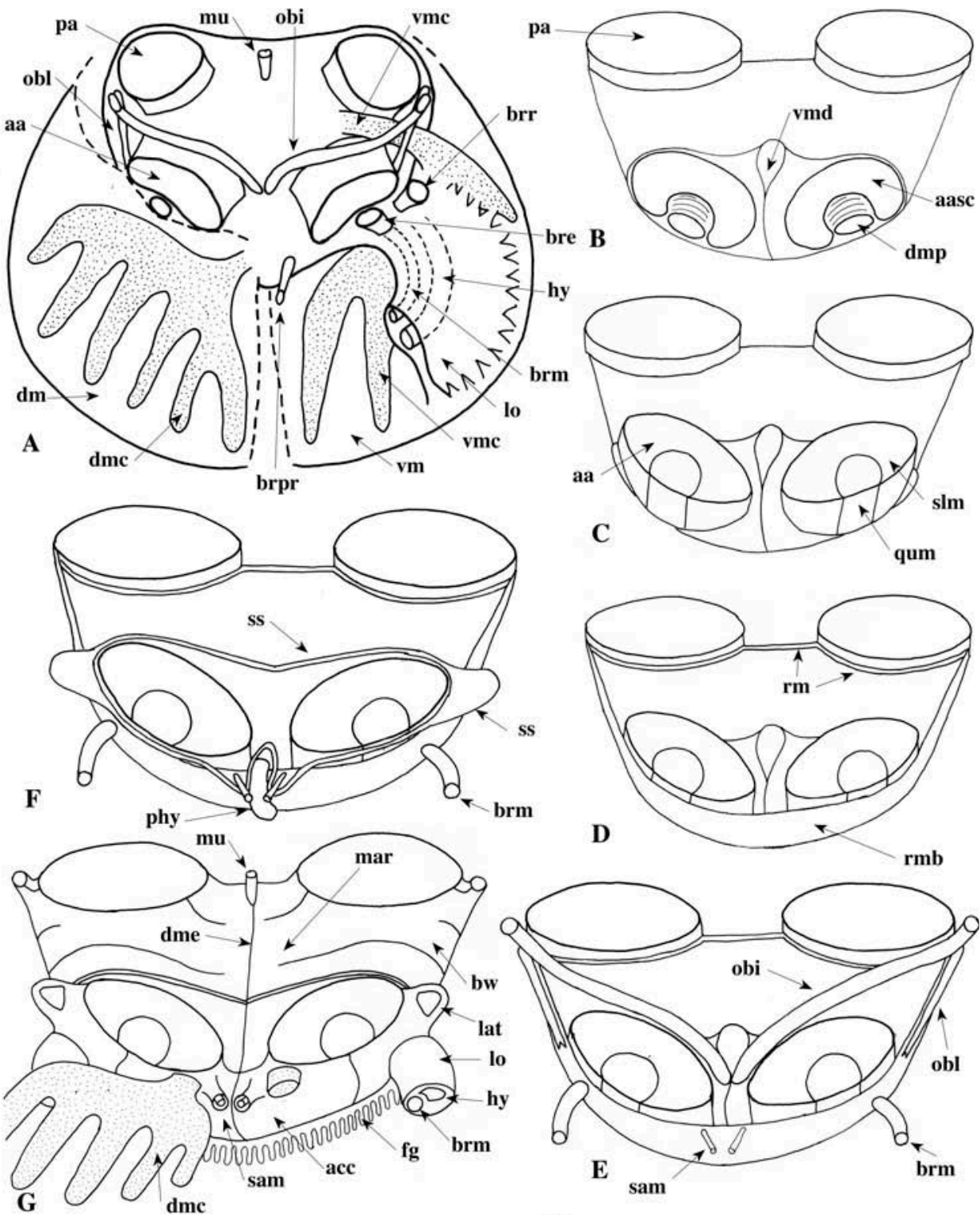

D
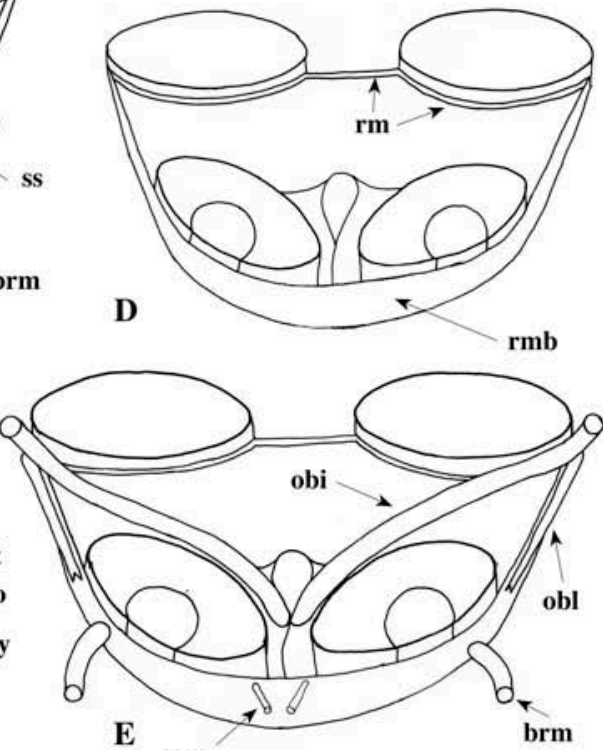

E

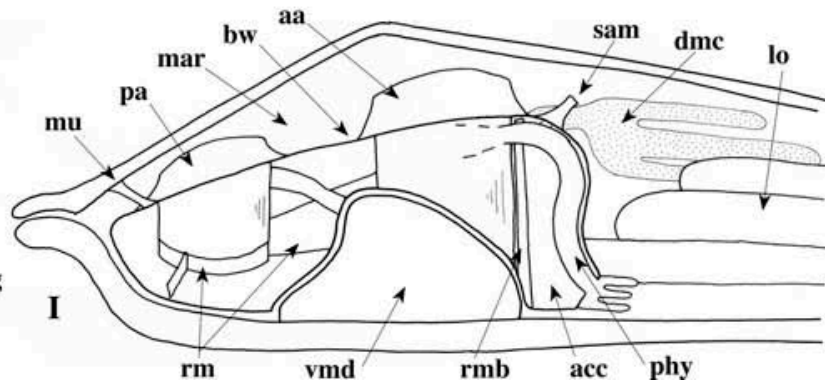


Table 2. Muscle names from Blochmann (1892) (angliscized) and the muscle name changes and new muscle terminology introduced in this study.

\begin{tabular}{|c|c|c|}
\hline Blochmann (1892) & This study & Comments \\
\hline 1. Brachial muscles & Brachial muscles & Retract lophophore arms \\
\hline $\begin{array}{l}\text { 2. Brachial elevator } \\
\text { muscles }\end{array}$ & $\begin{array}{l}\text { Anterior adductor } \\
\text { muscles }\end{array}$ & Quick-muscle, partially enclosed bundle \\
\hline $\begin{array}{l}\text { 3. Anterior adductor } \\
\text { muscles }\end{array}$ & $\begin{array}{l}\text { Anterior adductor } \\
\text { muscles }\end{array}$ & Slow-muscle, large curved bundle \\
\hline 4. & Ring muscle & $\begin{array}{l}\text { Attachment and support for brachial } \\
\text { muscle }\end{array}$ \\
\hline $\begin{array}{l}\text { 5. Oblique lateral } \\
\text { muscles }\end{array}$ & Oblique lateral muscles & Create hydrostatic pressure? \\
\hline $\begin{array}{l}\text { 6. Oblique internal } \\
\text { muscles }\end{array}$ & $\begin{array}{l}\text { Oblique internal } \\
\text { muscles }\end{array}$ & Slide and rotate the dorsal valve \\
\hline $\begin{array}{l}\text { 7. Brachial retractor } \\
\text { muscles }\end{array}$ & Support structure & Muscle tissue? Function unknown \\
\hline $\begin{array}{l}\text { 8. Brachial protractor } \\
\text { muscles }\end{array}$ & Small anterior muscles & Function unknown \\
\hline $\begin{array}{l}\text { 9. Median unpaired } \\
\text { muscle }\end{array}$ & $\begin{array}{l}\text { Median unpaired } \\
\text { muscle }\end{array}$ & Support the posterior gut \\
\hline
\end{tabular}

craniids as a pair of boomerang-shaped muscles, with the "brachial elevator" muscles as short oval muscles occurring in the wide "V" (Figure 1A). Williams et al. (1997) stated that the boomerang-shaped anterior adductor muscles of Novocrania "consist of two bundles of fibres". This study has seen no evidence to support this. This study suggests that a single, elongated, curving bundle of muscle fibres partially encloses the "brachial elevator" muscle fibre bundle. In all species dissected the two bundles of the anterior adductor muscle together form a single columnar structure, oval to sub-triangular in cross-section and enclosed in a single membrane (Figure 1C).

Articulated brachiopods and the inarticulated brachiopod Lingula (Kuga and Matsuno 1988) have two types of adductor muscle, striated quick-muscle, which

Figure 1. Line drawings of Novocrania illustrating anatomical features as described by Blochmann (1892) and this study. (A) Adaptation of two drawings of Novocrania anomala by Blochmann (1892). (B-G) Series of drawings showing muscles, ventral mound, new ring muscle, support structure, lophophore, anterior coelomic chamber and dorsal mantle canals. (H) Close-up of small anterior muscles and the anterior passage. (I) Cutaway drawing down midline. Abbreviations: aa, anterior adductor muscle; aasc, anterior adductor muscle scar; acc, anterior coelomic chamber; antp, anterior passage; bre, "brachial elevator muscle"; brm, brachial muscle; brr, "brachial retractor muscle"; brpr, "brachial protractor muscle"; bw, body wall; bwt, body wall tube; dm, dorsal mantle; dmc, dorsal mantle canal; dme, dorsal mesentery; dmp, dimple; fg, food groove; hy, hydrostatic skeleton; lat, lateral diverticulum; lo, lophophore; mar, mantle recess; mcc, mantle cilia current; mu, median unpaired muscle; obi, oblique internal muscle; obl, oblique lateral muscle; pa, posterior adductor muscle; phy, pharanyx; qum, quick muscle; rm, ring muscle; rmb, ring muscle belt; sam, small anterior muscle; slm, slow muscle; ss, support structure; vm, ventral mantle; vmc, ventral mantle canal; vmd, ventral mound. 

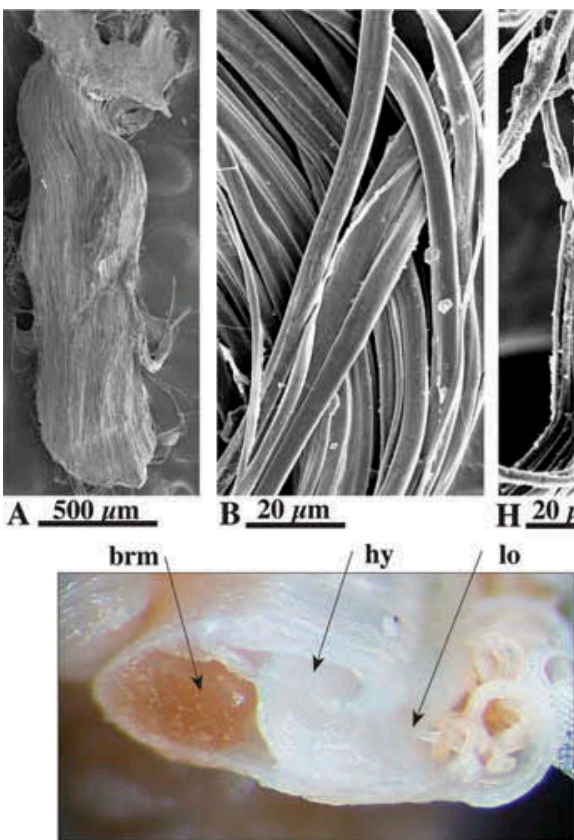

C. $100 \mu \mathrm{m}$

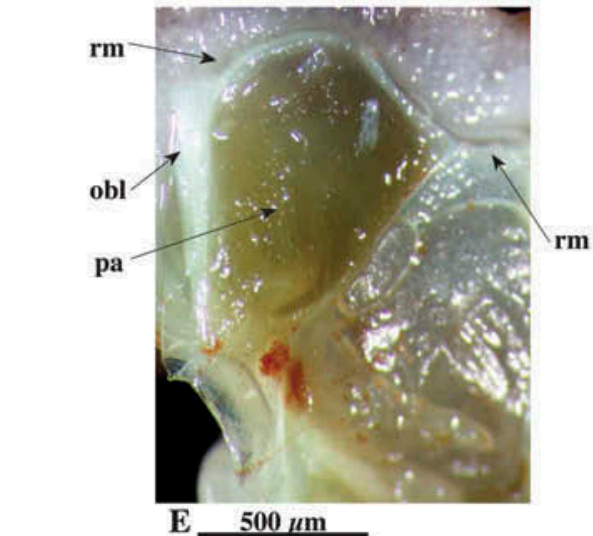

$\mathrm{H} 20 \mu \mathrm{m}$

lo

rm

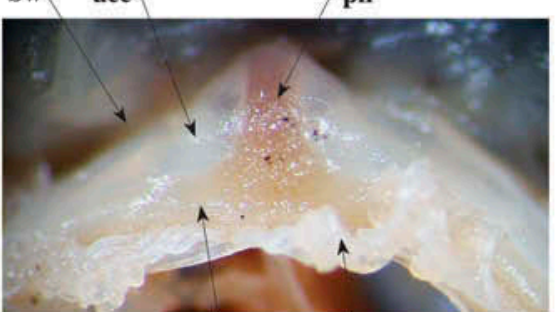

I $200 \mu \mathrm{m}$
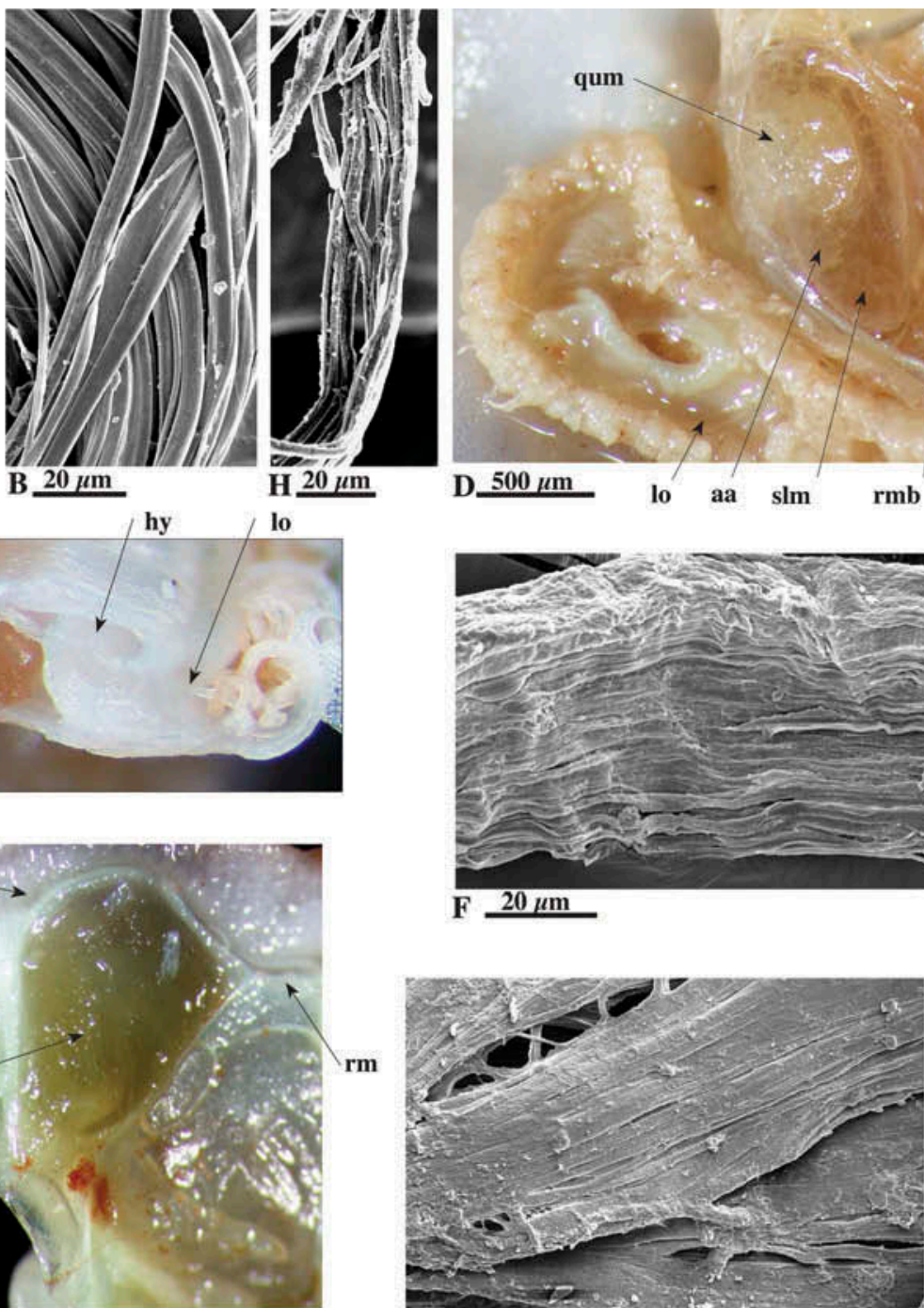

G $50 \mu \mathrm{m}$

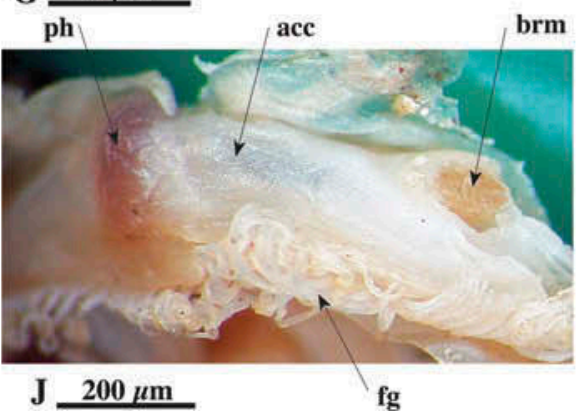

Figure 2. Digital and scanning electron micrographs (SEM) illustrating anatomical features. (A-H) Novocrania californica. (A). SEM of a piece of anterior adductor muscle, showing fibres make up whole length. (B) SEM close-up of fibres in A. (C) Lophophore cut to show brachial muscle and empty hydrostatic skeleton channel. (D) Ventral view of anterior adductor muscle, 
quickly closes the valves most of the way but lets them slowly open again immediately, and smooth slow-muscle which closes the valves completely and holds them closed (Rudwick 1970; Wilkens 1978b). This author is not aware of any study demonstrating the presence of quick-muscle in craniids, however, the snapping of valves to expel gametes and faecal pellets, observed in Novocrania (Rudwick 1970), can only be performed by quick-muscle (Wilkens 1978b). In Lingula the quick-muscle is translucent and the slow-muscle is opaque (Kuga and Matsuno 1988). In the craniid specimens dissected the enclosed bundle was translucent whereas the larger curved bundle was medium to dark-coloured (Figure 2D). In Terebratalia transversa (Sowerby, 1846) and Terebratulina unguicula (Carpenter, 1848) the quick striated muscle fibres are three to four times longer than the slow smooth muscle fibres (Wilkens 1978b). In the craniid species dissected the enclosed bundle is longer, sometimes significantly longer, than the curved bundle. This study suggests that the enclosed bundle is quick-muscle and the larger curved bundle is slow-muscle (Figure 1C).

\section{(4) The ring muscle (new structure)}

In all species dissected there is a ring of muscle around the four adductor muscles (Figure 1D), herein named the ring muscle. Where the posterior adductors attach to the ventral valve they are encircled, and connected, by a small ribbon of muscle (Figures 1D and 2E) composed of a single stack of flat, wide muscle fibres (Figure 2F). The ring muscle forms a wide belt anteriorly, composed of thin sheets of muscle (Figure 2G) across the anterior faces of the anterior adductor muscles (Figure 1D). The height of this belt decreases posteriorly. The brachial muscles of the lophophore arms attach to the anterior side of the ring muscle belt (Figure 1E) and this study suggests that a function of this ring muscle belt is to provide an anchoring point for the brachial muscles and a firm base to support the contractions of the brachial muscles that retract the lophophore (discussed below).

\section{(5) The oblique lateral muscles}

This pair of muscles attaches to the ventral valve posteriorly and to the body wall anteriorly (Figures 1E and 2E). This study disagrees with Williams et al. (1997) that the oblique lateral muscles of Novocrania are involved with the swivelling and sliding motions of the dorsal valve. As the body wall does not contact the dorsal valve (discussed below), these muscles will have little direct effect upon the dorsal valve. These muscles may be involved in creating hydrostatic pressure to open the valves (Gorjansky and Popov 1985, 1986).

showing translucent quick muscle and dark slow muscle, lophophore and ring muscle belt. (E) Ventral view of posterior adductor muscle enclosed by ring muscle and flanked by oblique lateral muscle. (F) SEM of ring muscle, a stack of wide flat fibres. (G) SEM of ring muscle belt, composed of thin sheets of muscle. (H) SEM of fibres of support structure. (I, J) Novocrania huttoni. (I) Ventral view of anterior tip of body, anterior coelomic chamber on each side of pharanyx beneath body wall. (J) Oblique ventral view of anterior coelomic chamber with cut brachial muscle. Abbreviations: aa, anterior adductor muscle; acc, anterior coelomic chamber; brm, brachial muscle; bw, body wall; fg, food groove; hy, hydrostatic skeleton; lo, lophophore; obl, oblique lateral muscle; pa, posterior adductor; ph, pharynx; qum, quick-muscle; rm, ring muscle; rmb, ring muscle belt; slm, slow-muscle. 


\section{(6) The oblique internal muscles}

These muscles attach to the dorsal valve laterally of the posterior adductor muscles and to the ventral valve between the anterior adductor muscles, following an S-shaped curve (Figure 1E), in all species dissected except for Ne. norfolki (Figure $3 \mathrm{~A}$ ) and $N$. lecointei. In these two species the muscle is larger, straight, wide and horizontally flattened; the dorsal attachment surface of the muscle faces medially rather than ventrally, on the dorsal valve in N. lecointei and on two dorsal spurs in Ne. norfolki (Figure 3B-D). As the dorsal valves of Ne. norfolki are very inflated, the extra mass of shell and/or the larger amount of water to be displaced by sliding or rotating movements may be the reason for the relatively large muscles. This study suggests that it is only the oblique internal muscles that create the sliding and rotating movements of the dorsal valve.

\section{(7) The "brachial retractor" muscles}

Joubin (1886) first named these muscles retracteurs des bras. Blochman (1892) used retractores brachorum (Figure 1A) and stated (in German) that while the "brachial retractor" muscles of $N$. anomala superficially resemble muscles, they are a different kind of tissue, which he named Stützsubstanz or support structure, consisting of bundles of very slim tubes with an outer layer of muscle fibres and a distal layer of connective cells connecting it to the "brachial retractor" muscle scar.

Bulman (1939) produced figures of the muscle systems of some inarticulated brachiopods, including Novocrania, based on the work of Hancock (1859), Joubin (1886) and Blochmann (1892). Bulman repeated Blochmann's assertion (in English) that in Novocrania the "retractor muscle" is not a muscle, but a "diverticulum of the coelom where muscle fibres are developed". Bulman did not mention the support structure of Blochmann and his figure of craniid musculature (Bulman 1939, fig. 4) excluded the "brachial retractor" muscles. Williams et al. (1997, fig. 84) used Bulman's illustration without "brachial retractor" muscles but included them in the description of craniid musculature.

Scanning electron micrographs of the adductor, oblique and "brachial protractor" muscle fibres of $N$. anomala show them to be 4-6 $\mu \mathrm{m}$ wide, 1-2.5 $\mu \mathrm{m}$ thick, flattened and closely packed (Figure 2B). Scanning electron micrographs of the "brachial retractor" muscle tissue from $N$. anomala show that it consists of smaller, more variable, round to flattened fibres, $1-4 \mu \mathrm{m}$ in diameter/width (Figure $2 \mathrm{H}$ ).

The "brachial retractor" muscles do not attach to the lophophore, as suggested by Joubin (1886), and are therefore misnamed. This study suggests that the name given by Blochmann (1892), support structure, is appropriate until the nature of the tissue and the function can be determined. For the "diverticulum of the coelom" where the support structure, sheathed in body wall, attaches to the dorsal valve this study suggests the name lateral diverticulum after Bulman (1939) (Figure 1G).

Where the support structure attaches to the dorsal valve, lateral to the anterior adductor muscles, it is purse-shaped (Figure 1F, G) and slim white ribbons (less than $50 \mu \mathrm{m}$ wide) of tissue emerge from each side. The anterior ribbons run anteromedially and loop around the "brachial protractor muscles", whereas the posterior ribbons curve around the anterior adductor muscles and run medially. The ribbons may be beneath or on top of the body wall. Both ribbons appear to attach to the dorsal mesentery (Figure 1G).

These ribbons of tissue were found in all five ethanol-preserved Novocrania species but in Neoancistrocrania norfolki the lateral diverticulum was empty of tissue. 
It is possible that the support structure is muscle tissue; where it attaches to the dorsal valve myotest occurs as in other craniid muscle scars (Krans 1965). Or, as Blochmann (1892) suggested, it may be another kind of tissue.

\section{(8) The "brachial protractor" muscles}

Joubin (1886) first named these muscles protracteurs des bras. Blochman (1892) used the term protractores brachorum and noted "there is little to say about these muscles". His figures show that they attach anteriorly to the dorsal valve outside the body wall, then attach to or pass through the body wall posteriorly (Figure 1A). Blochmann stated that in $N$. anomala they are sheathed in support structure. This study suggests that the "brachial protractor" muscles are sheathed in a thin membrane, like other muscles, and that the support structure ribbons curve around the dorsal attachment points of these muscles (Figure 1F). The "brachial protractor" muscles are loosely enclosed in two tubes of body wall in $N$. anomala, $N$. huttoni and $N$. lecointei (Figure $1 \mathrm{G}-\mathrm{H})$, on each side of the anterior body wall apex.

This author observed that the "brachial protractor" muscles attach to the ring muscle belt at their posterior end (Figure 1E), not to the lophophore, and are therefore misnamed. This study has no suggestions for the function of these tiny muscles and proposes the function-neutral name small anterior muscles.

\section{(9) The unpaired median muscle}

This small muscle attaches to the midline of the dorsal valve at the posterior and to the last stage of the gut, just before the anus (Figure 1A, G, I). Presumably it is able to raise the anus dorsally, and perhaps pull it a little posteriorly, which may help with the excretion of waste pellets and placement of them into cilia-created currents (discussed below) to disperse them.

\section{Description of the body wall, anterior coelomic chamber (new structure), anterior pouch (new structure), dorsal mantle canals, mantle recess, cilia currents and muscle-raising structures}

\section{The body wall}

The body walls of inarticulate lingulids and discinids contain dermal muscles used to open the valves (Emig 1982); these muscles are not found in the body wall of craniids. In all species dissected the body wall is a thin, transparent to sub-transparent membrane, sub-triangular to sub-quadrate in outline, that contains the visceral cavity, enclosing the gut, gonads and muscles (Figures 1G, I, and 3B). Anterior to the muscle belt in Novocrania is a long, thin, elbow-shaped, fluid-filled chamber, laterally extending to, or past, the base of lophophore arms, herein termed the anterior coelomic chamber (Figures 1G, I, and 2I, J). The apex occurs where the body wall curves over the pharnyx-oesophagus (which passes dorsally through the ring muscle belt) and down to the food groove (Figures 1F, I, and 2I, J). Neoancistrocrania norfolki does not have an anterior coelomic chamber. The body wall of Ne. norfolki attaches to the anterior and posterior edges of the winged process forming a dorsally directed pouch, herein termed the anterior pouch (Figure 3B, C, E). Part of the gut of $\mathrm{Ne}$. norfolki forms a dorsally directed half loop within the anterior pouch (unpublished data, J.H. Robinson). 

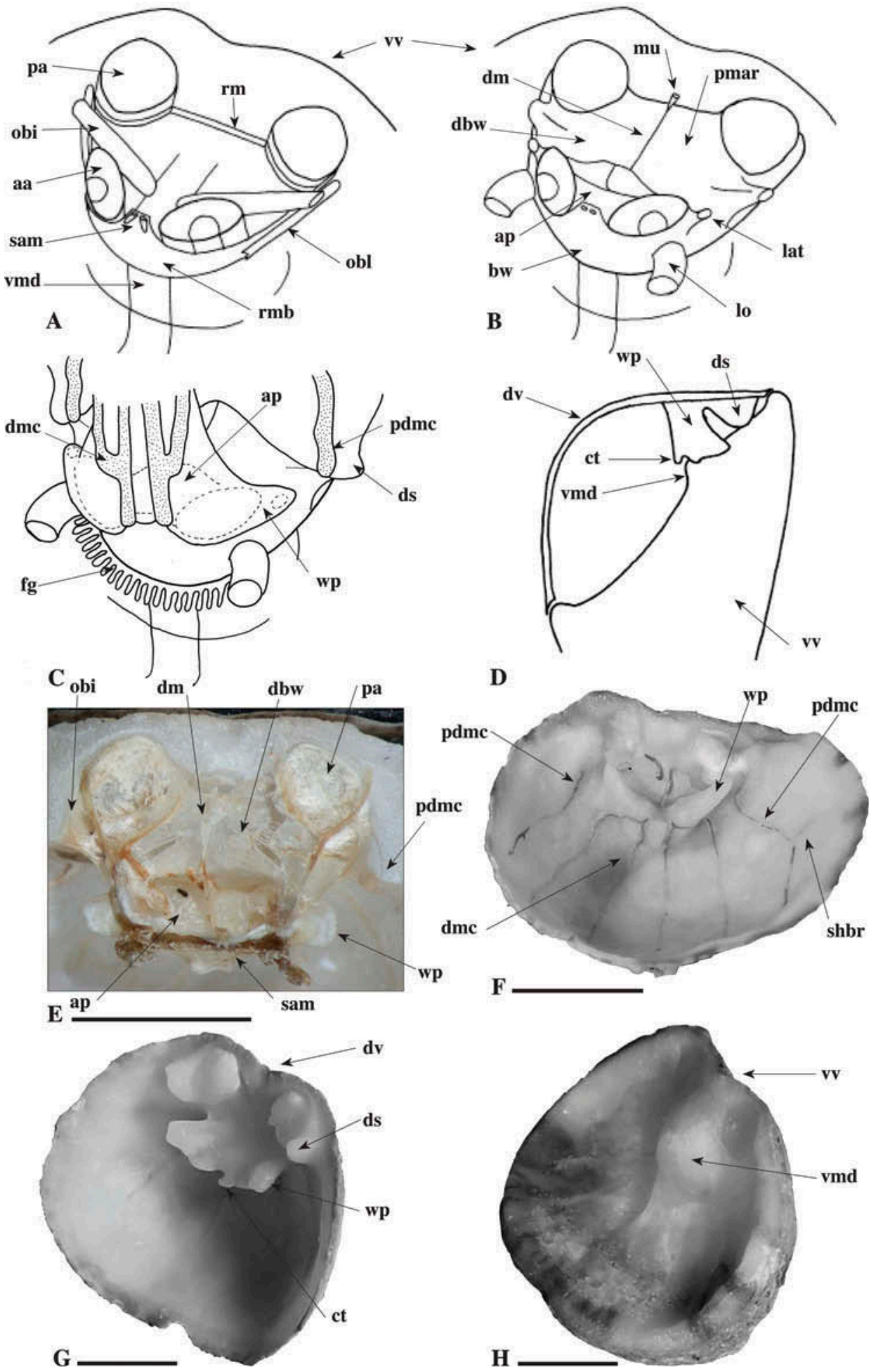


\section{The mantle canals (vascula lateralia)}

The translucent dorsal mantle covers the surface of the dorsal valve, except where the various muscles and support structure attach to the valve. Blochmann (1892, figs. 5-7) and Williams et al. (1997, fig. 71) figured the mantle canals of $N$. anomala and showed the dorsal canals emerging as two main stems from the anterior apex of the body wall (Figure 1A and $\mathrm{G}$ ) with the ventral canals emerging laterally in grooves in the ventral valve, one main stem on each side between the posterior and anterior adductor muscles (Figure 1A). The main stems then branch into secondary, and occasionally in Novocrania, tertiary branches (Williams et al. 1997). In $N$. californica the main stem of the dorsal mantle canals is very short and opens from the anterior side of the anterior adductor muscles. In Ne. norfolki the winged process provides a scaffold for the main stems of the dorsal mantle canals to reach from the anterior tip of the body wall to the dorsal valve, and the stem branches on the process (Figure 3C and F). In $\mathrm{Ne}$. norfolki, and unique to this taxon, there are two extra dorsal mantle canals at the posterior where the oblique internal muscles attach to the dorsal spur (Figure 3C and F). The dorsal mantle canals of Ne. norfolki form six subparallel lines running posterior to anterior. In all Ne. norfolki specimens examined the posterior dorsal canals only once formed a short lateral branch (Figure 3F). The volume within the valves of Neoancistrocrania is considerably larger than that of Novocrania species, because of the strongly domed dorsal valve (unpublished data, J.H. Robinson). The inner surface area of the dorsal valve of Neoancistrocrania will also be relatively larger than in Novocrania with more punctae and mantle tissue and this study suggests that the posterior mantle canals may have evolved to provide this extra surface area with a means of transporting nutrients.

\section{The mantle recess and cilia currents}

In all species dissected there is a gap between the upper surface of the body and the dorsal valve surface (Figure 1I), as illustrated for $N$. anomala by Blochmann (1892, figs. 10-15), Delage and Hérouard (1897, pl. 41), Atkins and Rudwick (1962, fig. 1) and Chuang (1974, fig. 2c). Only the posterior and anterior adductor muscles, median unpaired muscle, oblique internal muscles, small anterior muscles and support structure attach to the dorsal valve (Figure 1I). This creates a Rueckenhoehle (Blochmann 1892) or mantle recess (Chuang 1974) (Figure $1 \mathrm{G}$ and I). In lateral view the body is wedge shaped, highest anteriorly and lowest posteriorly (Figure 1I). In N. anomala

Figure 3. Line drawings and digital photographs illustrating the valves and anatomy of Neoancistrocrania norfolki. (A-C) Series of drawings showing muscles, body wall, ventral mound, anterior pouch, winged process and dorsal mantle canals. (D) Cutaway drawing of valves down midline. (E) DW 1657c. Close-up of dried anterior pouch and dorsal body wall. (F) DW 1657a. Ventral view of tilted dorsal valve showing dorsal mantle canals and single short branch. (G, H) DW 1657b. Oblique photographs of dorsal and ventral valve interiors. All scale bars $5 \mathrm{~mm}$. Abbreviations: aa, anterior adductor muscle; ap, anterior pouch; bw, body wall; ct, central tip; dbw, dorsal body wall; dm, dorsal mesentary; dmc, dorsal mantle canal; ds, dorsal spur; dv, dorsal valve; fg, food groove; lat, lateral diverticulum; lo, lophophore; mu, median unpaired muscle; obi, oblique internal muscle; obl, oblique lateral muscle; pa, posterior adductor muscle; pdmc, posterior dorsal mantle canal; pmar, partial mantle recess; rm, ring muscle; rmb, ring muscle belt; sam, small anterior muscle; shbr, short lateral branch of posterior mantle canal; vmd, ventral mound; vv, ventral valve; wp, winged process. 
the dorsal mantle cilia create inhalant currents from the posterior commissure that flow anteriorly through the mantle recess, and also lateromedially between the posterior and anterior adductors, that become part of the anterior median exhalant current created by the lophophore (Figure 4A, adapted from Orton 1914, fig. 2 and Chuang 1974, fig. 2a). Craniid brachiopods have an anus, found at the posterior of the body (Figure 4B, adapted from Williams et al. 1997), and Chuang (1974) suggested that this current is the means of removing wastes. In adult $N$. anomala, at the anterior apex of the body wall, there is a distance between the body surface and the dorsal valve of $0.2 \mathrm{~mm}$ when the valves are closed and $0.9-1.2 \mathrm{~mm}$ when the valves are open (Chuang 1974). Above the apex is a small opening between the small anterior muscles (Chuang 1974), herein termed the anterior passage (Figures 1H, and 4A), for the posterior-anterior dorsal mantle cilia current to pass through.

Novocrania lecointei and $N$. huttoni also have a full mantle recess and anterior passage. Novocrania californica (Figure 4C-E), N. japonica (Figure 4F-H) and Ne. norfolki (Figure 3C, D) have only a partial mantle recess, the muscle-raising structures of the dorsal valve appear to obstruct any possibility of an anterior passage. Presumably the mantle cilia of these three species still create currents through the space between the dorsal surface of the body wall and the dorsal valve. Such ciliary currents might flow in posteriorly and exit laterally or vice versa.

\section{The muscle-raising structures}

The muscles of craniids are attached, on one or both valves, to muscle-raising structures that lift the attachment point of some muscles away from the valve surface. These structures vary considerably among extant and fossil craniid genera and species and have been given a variety of names. On the dorsal valve the anterior adductor and small anterior muscles and the support structure may attach directly to the valve surface, to long platforms or septa-like walls that reach the valve margins, or to free-standing pedestals, processes or spikes. On the ventral valve the anterior adductor muscles and internal oblique muscles attach to calcitic or organic mounds. This study has avoided using the term ridge when describing muscle-raising structures; this term has been used for such a variety of muscle-raising structures in craniids that it has become meaningless.

All species examined have a muscle-raising structure on the ventral valve, the ventral mound. In $N$. californica (Figure 4C, E), $N$. japonica (Figure 4G, H), $N$. turbinata and $N e$. norfolki (Figure 3D, H) the ventral mound is calcitic; in $N$. lecointei (Figure 5A, B), N. anomala (Figures 1B and 5C), and $N$. huttoni the ventral mound (and the ventral posterior adductor attachment surfaces) is composed of an organic material that is translucent to amber in colour, firm and springy in fresh specimens but is crushed when pressed hard and shrinks markedly when dried. In $N$. anomala the outline of the ventral mound is a batwing shape and is visible in dead ventral valves where the organic part has decayed away (Figure 5D). The ventral valve of $N$. lecointei (Figure 5A, B) and $N$. huttoni is a very thin, translucent, organic film lying directly on the substrate and the organic ventral mound (and posterior adductor attachment surfaces) appear to lie upon this film.

In $N$. lecointei, $N$. huttoni and $N$. anomala (Figure 5E) the muscles and support structure attach to the dorsal valve surface and the muscle scars may be slightly raised, flush with the valve surface or slightly sunken. In $N$. californica the 


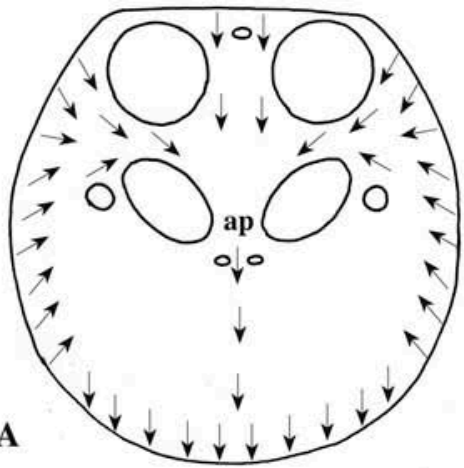

B

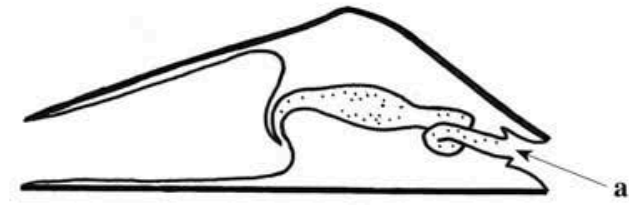

C
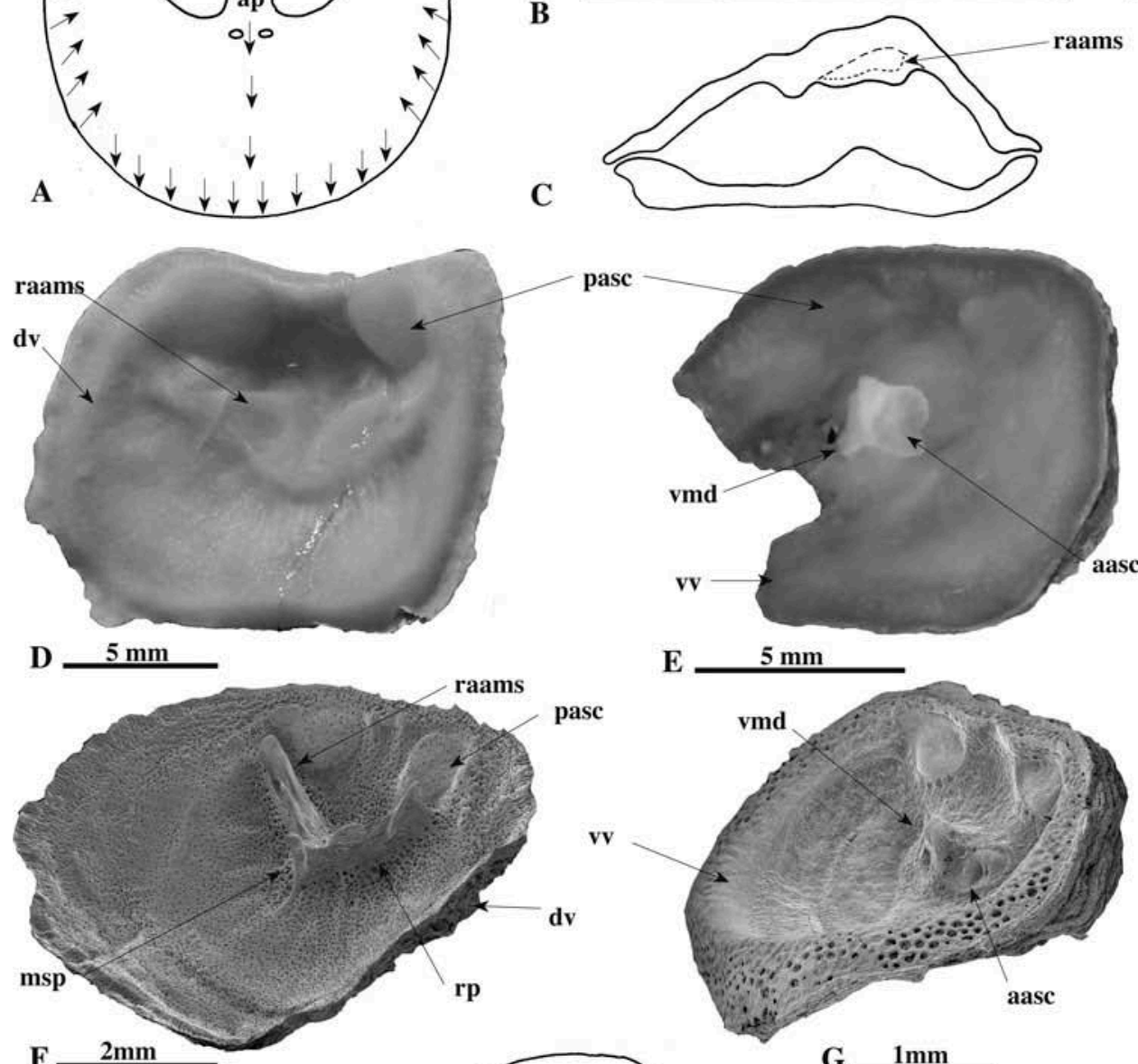

$\mathbf{E}$

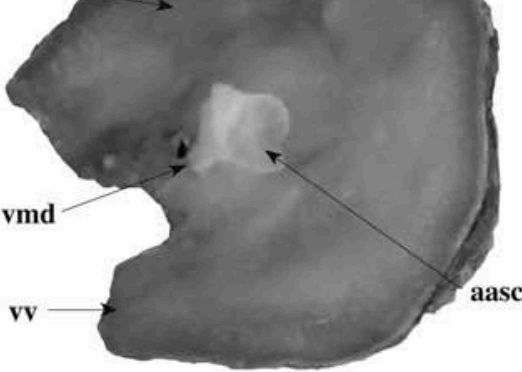

pasc

$5 \mathrm{~mm}$

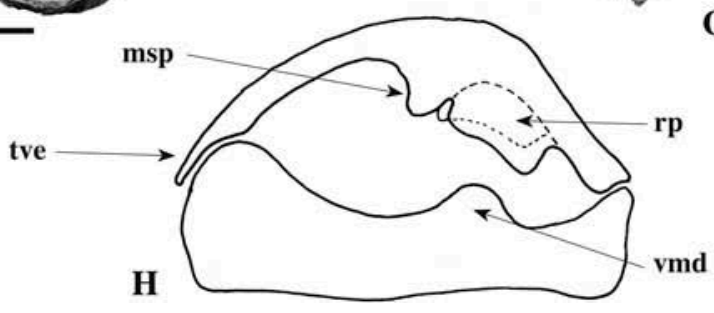

G $1 \mathrm{~mm}$

Figure 4. Line drawings and digital photographs illustrating cilia current flow and valve features of two species. (A) Diagram showing flow directions of dorsal mantle cilia currents. (B) Diagram of craniid valves and body (after Williams et al. 1997). (C-E) Novocrania californica. C. Cutaway drawing down midline of valves and muscle raising structures. (D, E) OU 44518a-b. Oblique photographs of dorsal and ventral valve interiors. $(\mathrm{F}-\mathrm{H})$ Novocrania japonica. (F, G) TUM 951117a. Oblique photographs of dorsal and ventral valve interiors. $(\mathrm{H})$ Cutaway drawing down midline of valves and muscle raising structures. Abbreviations: a, anus; aasc, anterior adductor muscle scar; $\mathrm{dv}$, dorsal valve; msp, median spike; pasc, posterior adductor muscle scar; raams, raised anterior adductor muscle scar; rp, raised pedestal; tve, thin valve extension; vmd, ventral mound; vv, ventral valve. 

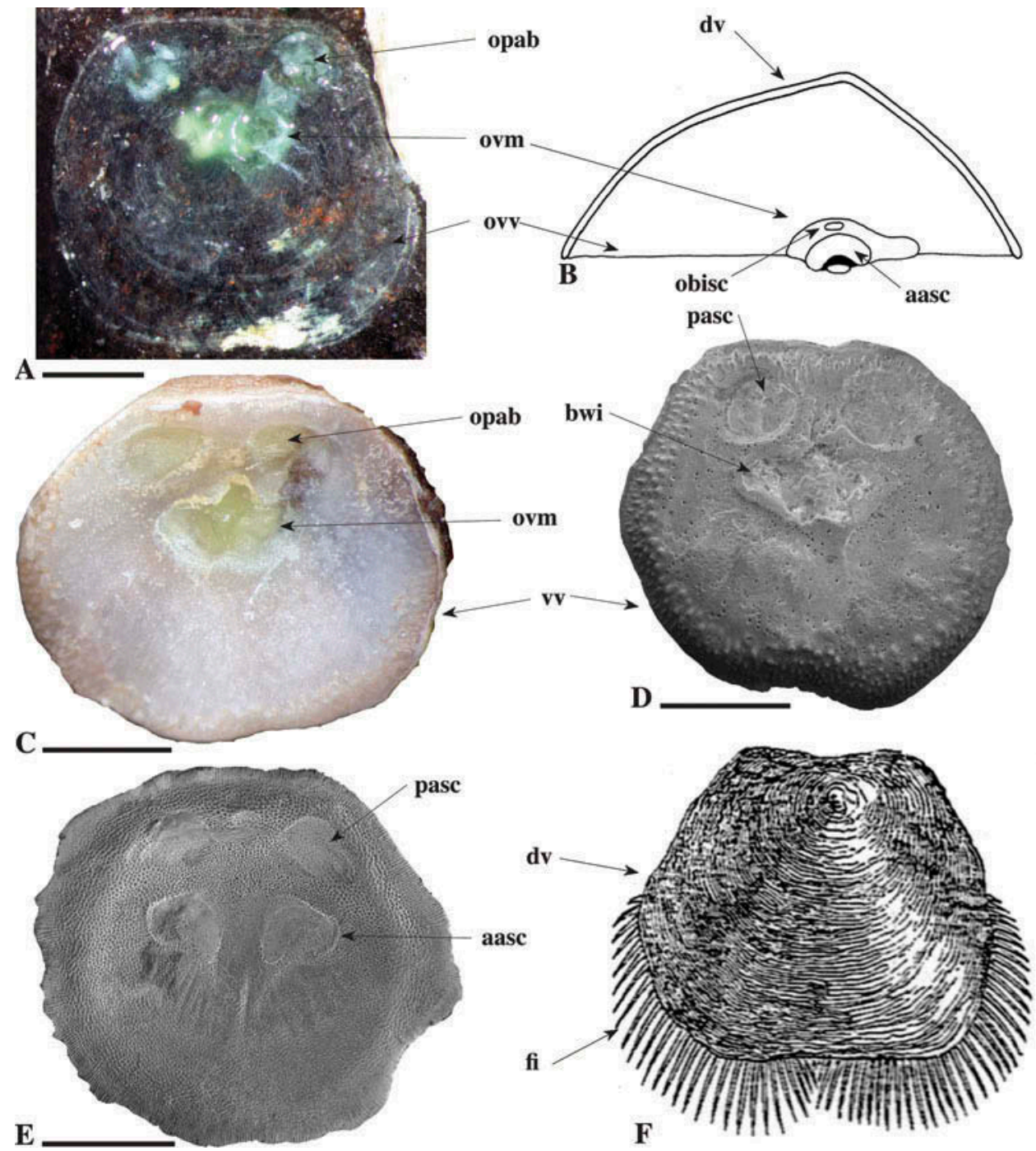

Figure 5. Line drawings and digital and scanning electron micrographs illustrating organic ventral mounds and lophophore filaments. (A, B) Novocrania lecointei. (A) NIWA 37947. Transparent organic ventral valve with organic ventral mound on dark rock. (B) Cutaway drawing down midline. (C-F) Novocrania anomala. (C) OU 44526a. Ventral valve with organic ventral mound. (D) OU 44525a. Ventral valve with organic mound rotted away. (E) OU 39355. Dorsal valve with muscle scars flush with valve surface. (F) Reproduction of illustration of $N$. anomala with lophophore filaments extended (from Barrett 1856). All scale bars $2 \mathrm{~mm}$. Abbreviations: aasc, anterior adductor muscle scar; bwi, "batwing" shaped outline of organic ventral valve; dv, dorsal valve; fi, filaments; obisc, oblique internal muscle scar; opab, organic posterior adductor base; ovm, organic ventral mound; ovv, organic ventral valve; pasc, posterior adductor muscle scar; vv, ventral valve. 
anterior adductor and small anterior muscles and the support structure attach to modestly raised muscle scars on the dorsal valve (Figure $4 \mathrm{C}, \mathrm{D}$ ). The dorsal valves of $N$. japonica (Figure $4 \mathrm{~F}, \mathrm{H}$ ) and $N$. turbinata have two pedestals and a median spike that on three sides hang above the ventral mound (Figure 4G). The muscle scars of the pedestals are angled medio-posteriorly, the slope varying from shallow to steep. The anterior adductor muscles and the support structure attach to the pedestals, and the small anterior muscles attach to the median spike. The dorsal valve of $\mathrm{Ne}$. norfolki has a single tall winged process that wraps around the strongly raised mound on the ventral valve (Figure 3C, D). The anterior adductor muscles and the empty lateral diverticula attach to the two lateral wings, while the small anterior muscles attach to the central tip of the process (Figure 3D). The anterior adductor muscle scars on both valves slope steeply, medioposteriorly on the dorsal valve, latero-anteriorly on the ventral valve. Neoancistrocrania norfolki also has two dorsal spurs, calcitic mounds lateral of the posterior adductor muscles where the oblique internal muscles attach to the dorsal valve (Figure 3C, G).

Laurin (1992) stated that the tall winged process found in Neoancistrocrania supported the lophophore. This study observed that the lophophore arms of Neoancistrocrania attach to the ring muscle belt and body wall (Figure $3 \mathrm{~A}-\mathrm{C}$ ), and are not supported by the winged process in the sense of the loop of articulated brachiopods. The lophophores of craniids have internal musculature and a hydrostatic skeleton and do not need support.

\section{Discussion \\ Discontinuation of old muscle names}

This study suggests that the use of the muscle names, "brachial protractor", "brachial retractor" and "brachial elevator" (Figure 1A) be discontinued for all Craniidae as none of these names correctly describes the functions of these muscles. These names were originally created for descriptions of a single living species, $N$. anomala, and have since been applied to many living and fossil genera.

\section{How, and how far, do the lophophore arms and filaments of craniids extend and retract?}

With the misnamed "brachial retractor" muscles (the support structure) and the "brachial protractor" muscles (the small anterior muscles) not able to fulfil these functions, it appears that the lophophore must use the hydrostatic skeleton and the brachial muscle within the arms to extend and retract (Figures 1A, G, and 2C). If the brachial muscle relaxes the hydrostatic skeleton would uncoil the arms slightly, moving them anteriorly and laterally. Contracting the muscle would coil and retract the arms again. Chuang (1974) gives an account of this. Small holes were drilled in the dorsal valves of living specimens of $N$. anomala to observe the flow of currents within the valves. The lophophore was extended when "the proximal whorl of each [lophophore arm] relaxed". Chuang (1974) noted that the filaments also extend and that the lophophore and filaments could be partially or fully extended. Atkins and Rudwick (1962) stated "the filaments may be withdrawn very rapidly ... by the 
contraction of the strand of striated muscle which runs up the frontal side of each filament".

Peck and Holmes (1989) stated that "much of the biomass of an inarticulate brachiopod is held outside of the shell for at least part of the time". However, the lophophore arms of Novocrania and Neoancistrocrania make up only a quarter to a half of the body mass (unpublished data, J.H. Robinson), and published illustrations of live specimens (Barrett 1856; Orton 1914, fig. 1; Atkins and Rudwick 1962, fig. 1a-b) show that only the filaments of the proximal whorl extended outside the shell when $N$. anomala was feeding. The sketch by Barrett (1856) is reproduced in Figure 5F. Joubin (1886) observed live specimens of $N$. turbinata in tanks for 14 months and stated they never extended their filaments outside the valves (Davidson 1888, English translation of the abstract from Joubin 1886). Specimens of $N$. japonica from one locality examined in this study (Okinawa) had a long, thin extension of the dorsal valve's anterior margin (Figure 4H). It seems unlikely that these specimens could have extended the filaments outside unless the valve was opened very wide. Specimens of $N$. japonica examined from another locality (New Caledonia) did not have this feature. It appears that some craniid species, or populations within species, may feed without extending the filaments outside the valves.

\section{How do craniids open their valves?}

There are several suggestions in the literature about how craniids raise their dorsal valve; by using the muscles, by increasing hydrostatic pressure within the valves, or by a combination of these. Thomson (1927) stated "When the anterior pair relaxes and the posterior pair contracts, the valves open in front to a limited extent, so that the posterior pair serve as diductors" (the valve-opening muscles in articulated brachiopods). Atkins and Rudwick (1962) suggested that when the massive columnar adductor muscles relaxed, the elasticity of the fibres might be enough to open the valves.

In articulated brachiopods the quick striated portion of the anterior adductor muscle rapidly, but incompletely, closes the valves; the slow smooth muscle of the adductor muscles then closes the valves tightly and can hold them closed for long periods. The diductor muscles open the valves and keep them open (Wilkens 1978a; b) as brachiopods keep their valves gaping most of the time and feed more or less continuously (Rudwick 1970). Articulated brachiopods with cut diductor muscles cannot open their valves (Wilkens 1978a). In the inarticulated brachiopod Lingula the valves are closed by quick and slow adductor muscles, but the valves in Lingula (Trueman and Wong 1987) and Discinisca (Emig 1997) are opened by hydrostatic pressure. This study suggests that it is unlikely that the family Craniidae alone of all brachiopod families (and all bivalve molluscs which open their valves by a ligament) has evolved a type of adductor muscle that is capable of opening their valves just by relaxing. However, once the valves are open and the adductor muscles are stretched back to their non-contracted length, they may passively keep the valves open, until they are innervated to close them again. An opening mechanism is still required and the use of hydrostatic pressure, as occurs in other inarticulated brachiopods, seems the most likely.

Hancock (in Davidson 1988) suggested that when the anterior adductors relax and the posterior adductors contract, the fluid in the coelomic chamber is pushed forward and the valves will "be opened a little in front". Bulman (1939) echoed 
Hancock and added that the oblique lateral muscles may partially control the opening process. Gutmann et al. (1978) stated that inarticulate brachiopods "possess a set of longitudinal muscles ... on contraction they pull the body into the posterior part of the shell ... the body can expand only dorsoventrally and hence forces the shell open." Popov et al. (2000) noted that the model of Gutmann et al. (1978) was "erroneous for the lingulides" but may be correct for the "craniiforms".

This model makes the assumption that dorsal body wall is in contact with the dorsal valve, as shown in Figure 4B (adapted from Williams et al. 1997), or is very close to the dorsal valve. However, there is a distinct gap between the dorsal body wall and the dorsal valve (Figure 1I); the apex of the dorsal valve is above the body. In Neoancistrocrania this gap is several millimetres. This study suggests that the body of craniids cannot expand dorsoventrally enough to open the dorsal valve and simply increasing the pressure in the coelom is not the opening mechanism.

In Novocrania the only place where coelomic fluid makes (almost) direct contact with the dorsal valve is in the dorsal mantle canals and perhaps at the dorsal tip of the loose tubes of body wall enclosing the small anterior muscles. All of these open off the anterior coelomic chamber (Figure 1G, I, 2I, J), which contains only coelomic fluid. Increasing hydrostatic pressure within the anterior coelomic chamber may explain how Novocrania open their dorsal valve, and this may be its primary function. The mantle canals are often full of globules (personal observation) and contain part of the animal's gonads (Williams et al. 1997) so the very beginning of the two dorsal mantle canals may be the dorsal valve's opening pressure points. There will be openings between the anterior coelomic chamber and the visceral cavity to allow circulation of coelomic fluid, but compression of coelomic fluid in a small, partly enclosed fluid chamber, directly beneath the valve opening pressure points may be more effective than compression of coelomic fluid in the whole body cavity, which would include the ventral mantle canals. There are no valves between the coelom in the visceral cavity and the mantle canals, as occur in Lingula (Trueman and Wong 1987).

This study suggests that when the oblique lateral muscles contract, the anterior body wall of Novocrania species would be pulled posteriorly, squeezing the anterior coelomic chamber and pressurizing the fluid inside. A quick squeeze may push open the dorsal valve before the pressure wave moves out of the chamber into the rest of the body and mantle canals.

Neoancistrocrania norfolki does not have an anterior coelomic chamber, but pressurized coelomic fluid in the anterior pouch and the empty lateral diverticula may be pressing against the winged process (Figure $3 \mathrm{C}$ ); these are possible dorsal valve opening pressure points in this taxon.

\section{Conclusions}

This study makes a number of suggestions and observations about the muscles, body wall, lophophore and valve opening mechanism and introduces two newly discovered soft-tissue structures. The "brachial elevator" muscles are part of the anterior adductor muscles; each is a small bundle of translucent quick-muscle partially enclosed by an elongate curved bundle of dark-coloured slow-muscle. The "brachial retractor" muscles are informally renamed support structure as the nature of the tissue is uncertain and their function unknown. A new ring muscle is described, small at the posterior and encircling the posterior adductors, and forming a wide belt at the 
anterior. The lophophore arms of craniids are extended and retracted by the hydrostatic skeleton and brachial muscles within the arms. The ring muscle belt is the attachment point for the brachial muscles, giving a firm base to support muscular contractions. A new name is proposed for the "brachial protractor" muscles, the function-neutral small anterior muscles; these attach posteriorly to the ring muscle belt, but their function is unknown. Neoancistrocrania has two extra dorsal mantle canals arising from the posterior and an anterior pouch in the body wall. The muscleraising structures of Neoancistrocrania do not support the lophophore. The dorsal body wall of craniids does not attach to or touch the dorsal valve. The oblique lateral muscles are probably not involved in movements of the dorsal valve; they attach to the body wall and when they contract may create hydrostatic pressure in the anterior coelomic chamber to open the dorsal valve. The dorsal valve opening pressure points may be at the beginning of the dorsal mantle canals in Novocrania and in the anterior pouch and lateral diverticula in Neoancistrocrania.

\section{Acknowledgements}

I would like to thank Bernard Cohen, University of Glasgow and Alan Logan, University of New Brunswick, for the gift of specimens; Michiko Saito and Kazuyoshi Endo, Tokyo University, Bruce Marshall, Te Papa Tongarewa, Wellington, Kareen Schnabel and Sadie Mills, NIWA, Wellington, Sarah Long and Lee Davies, Natural History Museum, London, Jann Thompson, Smithsonian Museum, Washington, for the loan of specimens, Daphne Lee Department of Geology, University of Otago, Leonid Popov, National Museum of Wales, Cardiff, and Bernard Cohen for their comments on the manuscript, Christine Keller for the translations of German text, Vickey Tomlinson, Department of Botany, University of Otago, Shelly Cameron, Department of Zoology, University of Otago for the loan of equipment and Liz Girvan of the Otago Centre of Electron Microscopy, University of Otago. Funding for this study was provided by the Division of Sciences, University of Otago.

\section{References}

Atkins D, Rudwick MSJ. 1962. The lophophore and ciliary feeding mechanisms of the brachiopod Crania anomala (Müller). J Mar Biol Assoc. 42:469-480.

Barrett L. 1856. Notes on the Brachiopoda observed on a Dredging Tour with Mr McAndrew on the Coast of Norway, in the summer of the present year. Ann Nat His, Ser 2. 16:257-259.

Bassett MG. 2000. Craniida. In: Kaesler RL, editor. Treatise on invertebrate paleontology, part H, brachiopoda (revised). Linguliformea, Craniiformea, and Rhynchonelliformea (Volume 2). Boulder (CO) and Lawrence (KS): Geological Society of America and University of Kansas Press; p. 169-183.

Blochmann F. 1892. Untersuchungen ueber den Bau der Brachiopoden. 1. Die Anatomie von Crania anomala, O.F. Müller. 4 Vols. Jena: Verlag Von Gustav Fischer.

Bulman OMB. 1939. Muscle systems of some inarticulate brachiopods. Geol Mag. 76:434 444.

Chuang SH. 1974. Observations on the Ciliary Feeding Mechanism of the Brachiopod Crania anomala. J Zool. 173:441-449.

Davidson T. 1886-1888. A Monograph of recent brachiopoda. Trans Linn Soc Lon. II. Ser 4; Zool. I. 1-74, 1886; II. 75-182, 1887; III. 183-248, 1888.

Delage J, Hérouard E. 1897. Traité de Zoologie Concrete 5. Paris: Les Vermidieus.

Emig CC. 1982. Terrier et position des Lingules (Brachiopodes Inarticulés). Soc Zool Fr. 107:185-194. 
Emig CC. 1997. Ecology of inarticulated brachiopods. In: Kaesler RL, editor. Treatise on invertebrate paleontology, part $\mathrm{H}$, brachiopoda (revised). Volume 1: introduction. Boulder (CO) \& Lawrence (KS): Geological Society of America \& University of Kansas Press; p. 473-502.

Gorjansky WJu, Popov LYe. 1985. Morphology, systematic position and origin of the inarticulate brachiopods with carbonate shells. Paleontol J. 3:3-14.

Gorjansky WJu, Popov LYe. 1986. On the origin and systematic position of the calcareous shelled inarticulate brachiopods. Lethaia. 19:233-240.

Gutmann WF, Vogel K, Zorn H. 1978. Brachiopods: biomechanical interdependences governing their origin and phylogeny. Science. 199:890-893.

Hancock A. 1859. On the organization of the Brachiopoda. Philos Trans R Soc. cxlviii:791-869.

Hancock A. In: Davidson T. 1988. A monograph of recent brachiopoda, part III. Trans Linn Soc Lon. III. 183-248.

Helmcke JG. 1939. Die Muskeln der Brachiopoden. Zool Jahresber. 72:99-140.

James MA. 1997. Brachiopoda: internal anatomy, embryology and development. In: Harrison FW, Woollacott RM, editors. Microscopic anatomy of invertebrates, volume 13: Lophophorates, Entoprocta and Cycliophora. Hoboken (NJ): Wiley-Liss Incorporated; p. 297-407.

Joubin L. 1886. Recherches sur l'anatomie des Brachiopodes Inarticules. Arch Zool Exp Gen Ser 2. 4:161-303.

Krans TF. 1965. Etudes morphologiques de quelques spiriferes Devoniens de la Chaine Cantabrique (Espagne). Leid Geol Med. 33:73-148.

Kuga H, Matsuno A. 1988. Ultrastructural investigations on the anterior adductor muscle of a Brachiopoda, Lingula unguis. Cell Struct Funct. 13:217-279.

Laurin B. 1992. D'ecouverte d'un squellette de soutien du lophophore de type "crura" chez un brachiopode inarticulé: description de Neoancistrocrania norfolki gen. sp. nov. (Craniidae). Comp Ren 1_Acad Sci Paris 314: 343-350.

Oehlert DP. 1887. Brachiopodes. In: Fischer P, editor. Manuel de Conchyliologie et Paléontologie conchyliologique, ou histoire naturelle des mollusques vivant et fossiles. Paris: F Savy; p. 1189-1334.

Orton JH. 1914. On ciliary mechanisms in Brachiopods, and some Polychaetes, with a comparison of the ciliary mechanisms on the gills of Molluscs, Protochordata, Brachiopods, and Cryptocephalous Polychaetes, and an account of the endostyle of Crepidula and its allies. Mar Biol Assoc UK J. 10:283-326.

Peck LS, Holmes LJ. 1989. Scaling patterns in the articulate brachiopod Liothyrella uva (Broderip, 1883). J Exp Mar Biol Ecol. 113:141-150.

Popov LE, Basset MG, Holmer LE. 2000. Craniata. In: Kaesler RL, editor. Treatise on invertebrate paleontology, part $\mathrm{H}$, Brachiopoda (Revised). Volume 2: Linguliformea, Craniiformea, and Rhynchonelliformea (part). Boulder (CO) \& Lawrence (KS): Geological Society of America \& University of Kansas Press; p. 158-164.

Rowell AJ. 1965. Inarticulata. In: Moore RC editor. Treatise on invertebrate paleontology. Part H: Brachiopoda. Research Series, Washington. Boulder (CO) and Lawrence (KS): Geological Society of America \& University of Kansas Press; p. 260-297.

Rudwick MSJ. 1970. Living and fossil brachiopods. London: Hutchinson University Library. Shipley AE. 1895. Brachiopods (Recent). Camb Nat Hist. 3:463-488.

Thomson JA. 1927. Brachiopod morphology and genera (recent and tertiary). Manual No. 7 Wellington: New Zealand Board of Science and Art.

Trueman ER, Wong TM. 1987. The role of the coelom as a hydrostatic skeleton in the lingulid brachiopods. J Zool. 231:221-232.

Wilkens JL. 1978a. Diductor muscles of brachiopods: activation and very slow contraction. Can J Zool. 56:324-332. 
Wilkens JL. 1978b. Adductor muscles of brachiopods: activation and contraction. Can J Zool. 56:315-323.

Williams A, James MA, Emig CC, Mackay S, Rhodes MC. 1997. Anatomy. In: Kaesler RL, editor. Treatise on invertebrate paleontology, part $\mathrm{H}$, brachiopoda (revised). Volume 1: introduction. Boulder (CO) \& Lawrence (KS): Geological Society of America \& University of Kansas Press; p. 7-188. 